\title{
Additive and non-additive effects for mature weight in beef cattle
}

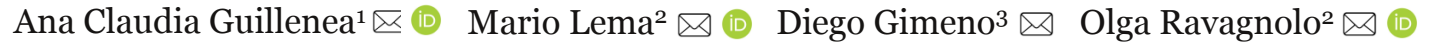 \\ Ana Carolina Espasandín ${ }^{3} \bowtie(1)$
}

Facultad de Agronomía, Universidad de la República, Avenida Garzón 780, CP 12900.

\begin{abstract}
Selection has emphasized animal growth, leading to an increase in their mature size affecting in some cases the pregnancy of the cows and the efficiency of the systems. Usually, crossbreeding improve productivity because of the genetic effects that the cows exploit, but the impact on mature weight (MW) has not been studied. The present study aimed at estimating MW and genetic parameters associated with the MW in crosses between two British breeds: Hereford (H/H) and Angus (A/A), a Continental: Salers (S/S), and a Zebu: Nelore (N/N). MW was analyzed at $4 ; 4.5 ; 5 ; 5.5$ and 6 years of age using a repeated-measure sire model. For parameters estimation, an additive - dominant model was used including the fixed effects of breed group, contemporary group, and age as covariate linear and quadratic, with the linear regression fitted by breed group. Permanent environmental and sire were included as random effects. According to the results, it is expected to observe heterosis between $\mathrm{H} / \mathrm{H}$ and N/N, however, the structure of the data may not be enough for estimate accurately the genetic parameters in this trait. The $\mathrm{A} / \mathrm{H}, \mathrm{N} / \mathrm{H}, \mathrm{S} / \mathrm{H}, \mathrm{S} / \mathrm{SH}$ and $\mathrm{H} / \mathrm{NH}$ cows were heavier than the $\mathrm{H} / \mathrm{H}$ cows. All the breed groups continue gaining weight until six years of age. The results revealed that British crossbred animals are heavier than $\mathrm{H} / \mathrm{H}$ at the first crossing but not in the following. Crossbred cows with proportions of 0.5 and greater for the Continental breed are heavier than $\mathrm{H} / \mathrm{H}$ cows. Crosses between British and Zebu cows have higher mature weight than $\mathrm{H} / \mathrm{H}$ at the first crossing and in backcrosses toward the British in all ages.
\end{abstract}

Key words: Crossbreeding, Heterosis, Cows, Maturity

\section{Efectos aditivos y no aditivos para el peso adulto en ganado de carne}

Resumen. La selección ha enfatizado el crecimiento de los animales llevando a un aumento en el tamaño adulto, que afecta en ocasiones la preñez de las hembras y la eficiencia del sistema. Los cruzamientos generalmente mejoran la productividad debido a los efectos genéticos que explotan las hembras, pero su impacto en el peso adulto (PA) no se ha estudiado. El objetivo del presente estudio fue estimar los parámetros genéticos asociados al PA y el PA en cruzamientos entre razas británicas: Hereford $(\mathrm{H} / \mathrm{H})$ and Angus $(\mathrm{A} / \mathrm{A})$, una continental: Salers $(\mathrm{S} / \mathrm{S})$ y una cebú: Nelore (N/N). El PA fue analizado a los 4; 4.5; 5; 5.5 y 6 años de edad utilizando un modelo padre de medidas repetidas. Para la estimación de los parámetros, se utilizó un modelo aditivo dominante que incluyó los efectos fijos del grupo racial, grupo contemporáneo y edad como covariable lineal y cuadrática, con la regresión lineal ajustada por grupo racial. El ambiente permanente y el padre fueron incluidos como efectos aleatorios. Según los resultados, se espera observar heterosis entre $\mathrm{H} / \mathrm{H}$ y $\mathrm{N} / \mathrm{N}$, sin embargo, la estructura de los datos puede no haber sido suficiente para estimar con precisión los parámetros genéticos en este rasgo. Las vacas $\mathrm{A} / \mathrm{H}, \mathrm{N} / \mathrm{H}, \mathrm{S} / \mathrm{H}, \mathrm{S} / \mathrm{SH}$ y $\mathrm{H} / \mathrm{NH}$ superaron a las $\mathrm{H} / \mathrm{H}$. Todos los grupos raciales continuaron aumentando de peso hasta los seis años de edad. Los resultados revelaron que los animales cruzas británicos son más pesados que $\mathrm{H} / \mathrm{H}$ en el primer cruce (F1), pero no en los siguientes. Las vacas cruzas con proporciones de 0.5 y mayores para la raza Continental son más pesadas que las vacas $\mathrm{H} / \mathrm{H}$. Los cruzamientos entre vacas británicas y cebú tienen un mayor peso adulto que las $\mathrm{H} / \mathrm{H}$ en el primer cruzamiento y en retrocruzas hacia la británica en todas las edades.

Palabras clave: Cruzamientos, Heterosis, Vacas, Madurez

Recibido: 2020-07-05. Aceptado: 2020-09-22

* Autor para la correspondencia: ana_guillenea@hotmail.com

${ }^{2}$ Instituto Nacional de Investigación Agropecuaria, INIA Treinta y Tres, Ruta 8 Km 282, CP 330oo. Treinta y Tres, Uruguay.

${ }_{3}^{3}$ Secretariado Uruguayo de la Lana, Camino Servando Gómez 2408, CP 11200. Montevideo, Uruguay

4 Instituto Nacional de Investigación Agropecuaria, INIA Las Brujas, Ruta 48 Km 10, CP 9020o. Canelones, Uruguay. 


\section{Introducción}

The mature cow weight (MW) is a crucial trait to determine the profitability and sustainability in the production system (Costa et al., 2011). About $70 \%$ of the energy requirements are needed for maintenance in the beef breed cycle (Ferrell and Jenkins, 1985). A bioeconomic model in Uruguay determined that increasing maternal weight at weaning has a negative economic impact on the beef cattle system since it led to higher feeding requirements of cows without increasing incomes (Pravia et al., 2014). Nevertheless, the authors found that carcass weight was the second trait in economic importance because of its contribution to income. MW have medium to high heritability and a positive genetic correlation with growth traits (Junior et al., 2019). This could lead to an increase in MW when selecting animals for higher growth rates. However, these animals are more efficient only when food is not restricted, but under limited resources, as in grazing systems, they are the least productive (Jenkins, 2009). An important point to manage the resources in a calf-producer enterprise is to understand in depth the effects involved in MW of different breed groups.

The main tools to improve animal production through genetic are selection within and among breeds and crossbreeding. Crossbreeding are widely used for their ability to take advantage of complimentary for many traits and to exploit additive and non-additive genetic differences among breeds. Biological variation has been reported to exist among cattle breeds for birth weight, meat quality, growth, and final weight (Kuehn and Thallman, 2016). The breed origins of beef cattle are widely bunched in Bos indicus and Bos taurus, and the last ones, in turn, in British and Continental breeds. Different breed origins allow selection and complimentary breed matings to choose the most appropriate genetic resource to obtain the highest economic profit. Crossbreeding parameters are estimated using genetic models to establish the difference in genetic merit of breeds and to select the most suitable breed group (Gregory and Cundiff, 1980).

The most common models used in large beef cattle populations are the additive - dominant model (Gardner and Eberhart, 1966) and the Dickerson model (Dickerson, 1969, 1973). The additive dominant model assumes that heterosis occurs for dominance effects. Riley and Crockett (2006) suggest that the expression of heterosis is determined by dominance effects at many genes, so that the heterosis is proportional to heterozygosity. The first cross of two animals belonging to two pure breeds results in a heterozygous animal at all its loci. Consequently, according to the additive - dominant model, F1 animals would be expected to express maximum heterosis, while F2 would be expected to retain half of the heterosis observed in the F1 generation. Additive and dominance effects are relatively simple to model; conversely, epistasis effects are more complex. The estimability of these parameters depends on complex designs that include many animals and breed groups (Kinghorn and Vercoe, 1989). Despite its importance, research studies to estimate crossbreeding parameters in beef cattle are scarce, particularly in mature traits. The objectives of this study were: (1) to estimate MW for Hereford and different crossbred cows, and (2) to estimate crossbreeding parameters in terms of additive and heterotic effects for MW of Hereford, Angus, Salers, and Nellore breed in temperate climate under grazing conditions.

\section{Materials and Methods}

\section{Management of the experiment}

The data used in this study were records of cow weight from beef herds of several experiments carried out in a commercial farm called "Capilla Vieja", located in the department of Paysandú, Uruguay that was part of a research project between Caja de Notarial de Seguridad Social and Facultad de Agronomía, Universidad de la República. The experiments were developed to estimate crossbreeding genetic parameters to evaluate the importance of different gene action (additive and non-additive) affecting economically important traits, as well as to assess the relative production of crossbreds with a different breed composition (Gimeno et al., 1995).

\section{Experimental design}

Four breeds of beef cattle were used: Hereford $(\mathrm{H} / \mathrm{H})$ and Aberdeen Angus (A/A) as representatives of British breeds, Salers (S/S) as Continental and Nellore $(\mathrm{N} / \mathrm{N})$ as Zebu breed.

The initial herd consisted of only $\mathrm{H} / \mathrm{H}$ females and $\mathrm{S} / \mathrm{S}$ and $\mathrm{N} / \mathrm{N}$ females were not available. Therefore, the crossbreeding scheme was optimized in order to design the best possible experiment given the restriction of having only one initial maternal breed to use and of not being able to have all the breed groups at the same time (Sölkner and James, 1990a). Gimeno et al. (1995) describe the strategy used in the design of the experiments. The optimization was carried out 
using the D-Optimally criterion of the Optimum Design Crossbreed Experiment program (Sölkner and Fucks, 1994), considering the Dickerson full genetic model with maternal effects.

The experiment started in 1993 with a herd of 500 adult $\mathrm{H} / \mathrm{H}$ cows. Two years later pure A/A cows were also included in the experiment. Few weights of pure A/A cows were recorded, therefore there were not used in the analyses. Given the lack of maternal $\mathrm{S} / \mathrm{S}$ and $\mathrm{N} / \mathrm{N}$.

The $\mathrm{H} / \mathrm{H}$ cows were annually mated with $\mathrm{A} / \mathrm{A}, \mathrm{H} / \mathrm{H}$, $\mathrm{N} / \mathrm{N}$, and $\mathrm{S} / \mathrm{S}$. In 1995, the first $\mathrm{F} 1$ and pure $\mathrm{H} / \mathrm{H}$ cows bred in the experiment were inseminated with the four purebreds and $\mathrm{F} 1$ bulls $(\mathrm{A} / \mathrm{H}, \mathrm{N} / \mathrm{H}$ and $\mathrm{S} / \mathrm{H})$ born in the experiment. Consequently, F1 and backcrosses were produced during eight years (Table 1). Because of the lack of pure $\mathrm{S} / \mathrm{S}$ and $\mathrm{N} / \mathrm{N}$ females, the records of pure females generated and analyzed in this study correspond only to $\mathrm{H} / \mathrm{H}$ cows.

The mating season stretched over twelve weeks (usually from 1 December to 20 February). The 698 cows analyzed in this study are progeny of 71 bulls: 24 A/A, $20 \mathrm{H} / \mathrm{H}, 14 \mathrm{~N} / \mathrm{N}$, and $13 \mathrm{~S} / \mathrm{S}$. The sires were selected prioritizing minimizing relationship, and they were used with different maternal breeds to obtain different breed groups of half-sibs from the same sire as recommend Sölkner and James (1990b). At least one bull was repeated per breed per year to connect the experiments. The herd remained under grazing conditions with $5500 \mathrm{~kg}$ dry matter/ha/year of production approximately. No supplementary feed was provided during the experimental period. See Lema et al. (2011) for a detailed description of general management on the herd.

Table 1. Number of cows born between 1993 and 2004 by maternal and paternal breed group. ${ }^{\text {a }}$

\begin{tabular}{ccrlrr}
\hline Dam breed group & \multicolumn{7}{l}{ Sire breed group } \\
\hline H/H & A/A & H/H & N/N & S/S & Total \\
A/H & 153 & 165 & 133 & 202 & 653 \\
N/H & 6 & 8 & & & 14 \\
S/H & & 9 & 5 & & 14 \\
Total & & 11 & & 6 & 17 \\
\hline
\end{tabular}

${ }^{a}$ Sire and dam breed group at the left and right of the slash, respectively. Breed group: Angus (A/A), Hereford (H/H), Nellore (N/N), Salers (S/S), Angus/Hereford (A/H), Nellore/Hereford (N/H) and Salers/Hereford (S/H)

\section{Data}

The mature weight was analyzed after $4 \mathrm{yr}$ of age. After editing, data consisted of a set of 7651 weight measures of 698 cows of 10 different breed groups: $\mathrm{H} / \mathrm{H}, \mathrm{A} / \mathrm{H}, \mathrm{N} / \mathrm{H}, \mathrm{S} / \mathrm{H}, \mathrm{H} / \mathrm{AH}, \mathrm{H} / \mathrm{NH}, \mathrm{H} / \mathrm{SH}, \mathrm{A} / \mathrm{AH}$, $\mathrm{N} / \mathrm{NH}$, and $\mathrm{S} / \mathrm{SH}$. As $\mathrm{H} / \mathrm{H}$ was the base-maternal breed, $93.5 \%$ of the cows had $\mathrm{H} / \mathrm{H}$ dam. The average number of records per cow was 7 (ranging from 2 for $\mathrm{N} / \mathrm{NH}$ to 12 for $\mathrm{S} / \mathrm{H}$ ). Records of cows without date of birth or weighing, and unidentified parents or breed group were excluded from the analyses. Additionally, records outside the range \pm 3 studentized residual (in absolute value) were deleted. Records of cows of less than $4 \mathrm{yr}$ of age and older than $8.5 \mathrm{yr}$ of age were also eliminated, as well as breed groups without observations from $6 \mathrm{yr}$ of age (except N/NH because it was needed to estimate the crossbreeding parameters). Thus, the range of ages used for the analyzes was from 4 to $8.5 \mathrm{yr}$ of age (5.4 $\mathrm{yr}$ on average), and the leastsquare means and crossbreeding parameters by breed group were estimated at 4, 4.5, 5, 5.5 and $6 \mathrm{yr}$ of age.

The cows were weighed roughly every 45 days between 1997 and 2002. Before each measurement, they were locked up approximately 12 hours. In grazing conditions with medium to a high quality of forage, these fasting hours represent a reduction of between 5 and $7 \%$ of the total live weight (Di Marco, 2006). The records of MW per breed group per age at measurement are presented in Table 2. The differences in age by breed group are common in the designs of crossbreeding experiments, where certain breeds are initially available, and they are required to generate subsequent generations. The $\mathrm{H} / \mathrm{H}$ and $\mathrm{F} 1$ cows were born in 1993, and they were weighted during the whole experiment. The first backcrosses daughters of F1 dams were born in 1996, consequently, they do not reach the $7 \mathrm{yr}$ of age in the trials. The experiments ended after weaning in autumn 2002, therefore the most advanced crossbred groups did not reach five years old. Thus recombination losses were not possible to estimate since the needed breed groups (Dickerson, 1969) did not reach necessary age for the expression of this trait.

The first edition was conducted using $\mathrm{R}$ Software ( $\mathrm{R}$ Development Core Team, 2016), and analyses were carried out using SAS (SAS Institute, 2014). 
Table 2. Number of weight records according to age of the cow per breed group ${ }^{\text {a }}$

\begin{tabular}{lrrrrrr}
\hline & \multicolumn{7}{c}{ Age of cows (yr) at measurement } \\
\cline { 2 - 7 } Breed group & $\mathrm{n}$ & 4 & 5 & 6 & 7 & 8 \\
\hline Purebred & & & & & & \\
H/H & 1849 & 389 & 665 & 524 & 180 & 91 \\
F1 & & & & & & \\
A/H & 1536 & 395 & 512 & 379 & 157 & 93 \\
N/H & 1577 & 351 & 519 & 392 & 197 & 118 \\
S/H & 2508 & 545 & 858 & 691 & 283 & 131 \\
\hline Backcrosses & & & & & & \\
H/AH & 35 & 17 & 12 & 6 & & \\
H/NH & 37 & 20 & 14 & 3 & & \\
H/SH & 31 & 20 & 9 & 2 & & \\
A/AH & 40 & 18 & 16 & 6 & & \\
N/NH & 10 & 6 & 4 & & & \\
S/SH & 28 & 14 & 8 & 6 & & \\
Total & 7651 & 1775 & 2617 & 2009 & 817 & 433 \\
\hline
\end{tabular}

a Sire and dam breed group at the left and right of the slash, respectively. Breed group: Hereford (H/H), Nellore (N/N), Salers (S/S), Angus/Hereford (A/H), Nellore/Hereforf (N/H), Salers/Hereford (S/H), Hereford/Angus-Hereford (H/AH), Hereford/Nellore-Hereford $(\mathrm{H} / \mathrm{NH})$, Hereford/Salers-Hereford (H/SH), Angus/Angus-Hereford (A/AH), Nellore/Nellore-Hereford (N/NH) and Salers/Salers-Hereford (S/SH).

Two codes were defined to assign to each record the physiological and lactation status affecting MW. A pregnancy code took a value of 1 when the record was in the range of 300 days before calving (pregnant) and o for the other records (empty). This range was taken as a reference since it was reported for Continental breeds (Sobek et al., 2015) and Bos indicus breeds (Chenoweth, 1994). The lactation status was assigned with another code that took a value of 1 when the record was between the calving date and one day after weaning (cows suckled), the records outside it took a value of o (dry). The records were assigned to their respective seasons, which were defined as summer from December to February, autumn from March to May, winter from June to August, and spring from September to November.

\section{Models of analysis of means and estimation of crossbreeding genetic parameters}

Preliminary analyses of variance were carried out to determine the relevance of fixed effects in the models (not shown). Significant effects were subsequently included in the analyses. As the mating was seasonal, calves were born in spring and early summer (September to December, mainly). They were allowed suckling and grazing with the cows, and weaned from their dams at about 6 months of age, with one weaning date for the whole herd. Due to this management, environmental effects and cow weights might be confounded. For this reason, contemporary groups (CG) were defined by a combination of lactation and pregnancy status, year, and season of measure. CGs with less than five observations were excluded from the analysis. Age as covariate linear and quadratic was also included in the analyses, with the linear regression fitted by breed group.

\section{Model of analysis of mature weight}

A repeated-measure sire model (Model 1) was used for the analyses of MW:'

$\mathrm{y}_{\mathrm{jklmn}}=\mu+\mathrm{BG}_{\mathrm{j}}+\mathrm{CG}_{\mathrm{k}}+\mathrm{c}_{\mathrm{l}}+\mathrm{s}_{\mathrm{m}}+\beta_{\mathrm{j}} \mathrm{x}+\beta \mathrm{x}^{2}+\mathrm{e}_{\mathrm{jklmn}}$

where $\mathrm{y}_{\mathrm{jklmn}}$ were the observations of $\mathrm{MW}$ of the $\mathrm{l}^{\text {th }}$ cow, of the $\mathrm{j}^{\text {th }}$ breed group, in the $\mathrm{k}^{\text {th }}$ contemporary group, progeny of the $\mathrm{m}^{\text {th }}$ sire, $\mu$ was the general mean, $B_{j}$ was the effect of the $j^{\text {th }}$ breed group $(j=1, \ldots, 10)$, $\mathrm{CG}_{\mathrm{k}}$ was the effect of the $\mathrm{k}^{\text {th }}$ contemporary group $(\mathrm{k}=1$, ..., 55), $\mathrm{c}_{1}$ was the permanent environmental effect of the $\mathrm{l}^{\text {th }}$ cow $\sim(\mathrm{o}$, o2c $)(1=1, \ldots, 698), \mathrm{s}_{\mathrm{m}}$ was the random effect of $\mathrm{m}^{\text {th }}$ sire $\sim\left(0, \sigma_{\mathrm{s}}^{2}\right)(\mathrm{m}=1, \ldots, 71)$, $\mathrm{x}$ was the age of the $1^{\text {th }}$ cow in the $n$ moment, $\beta_{j}$ was the regression coefficient of weight on age $x$ (linear) of the $\mathrm{j}^{\text {th }}$ breed group, $\beta$ was the regression coefficient of weight on age $\mathrm{x}$ (quadratic), $\mathrm{e}_{\mathrm{jklmn}}$ was the random residual effect of the jklmn ${ }^{\text {th }}$ observation $\sim\left(\mathrm{o}, \sigma^{2}{ }_{\mathrm{e}}\right)$.

The relationships among sires were not considered in these analyses. Statistical analyses were conducted using the PROC MIXED of SAS (SAS Institute, 2014), with the ESTIMATE statement to create the contrast and the LSMEANS statement to predict the means by breed group and age. 


\section{Model of analysis of crossbreeding effects}

The estimation of crossbreeding parameters was carried out applying the additive - dominant model. Maternal effects were not included in these statistical analyses due to they being considered important only until weaning (Koch, 1972; Sölkner and James, 1990a).

The least-square means and variance-covariance matrix per breed per age obtained from Model 1 were subsequently used to estimate the crossbreeding parameters by generalized least-squared analysis (GLS). To avoid linear dependencies between breed proportions, the additive effect coefficients were calculated as deviation from $\mathrm{H} / \mathrm{H}$.

The regression model used for the estimation of crossbreeding parameters (Model 2) was the following:

$$
\mathrm{BGM}_{\mathrm{ij}}=\mu+\alpha^{*} \mathrm{~g}_{\mathrm{i}}+\delta_{\mathrm{iH}} \mathrm{h}_{\mathrm{iH}}+\mathrm{e}_{\mathrm{ij}}
$$

where $\mathrm{BGM}_{\mathrm{ij}}$ was the vector of least-square means for MW for each breed group at each age estimated with the first model (Model 1), $\mu$ was an intercept, $g_{i}$ was the additive effect of the breed $i^{\text {th }}, h_{i H}$ was the heterosis effect because of crossing $i^{\text {th }}$ with $\mathrm{H} / \mathrm{H}, \mathrm{e}_{\mathrm{ij}}$ was the random residual effect $\left(\operatorname{var}\left(\mathrm{e}_{\mathrm{ij}}\right)=\sigma_{\mathrm{e}}^{2} \mathrm{~V}\right)$ ). V was the error variance-covariance matrix of $\mathrm{BGM}_{\mathrm{ij}}$, $\mathrm{a}_{\mathrm{i}}$ was the proportion of breed i contribution to the cow, which was calculated as $\alpha_{i}=1 / 2\left(\alpha_{i}^{\mathrm{S}}+\alpha_{i}{ }^{\mathrm{D}}\right)$, and was expressed as difference from $\mathrm{H} / \mathrm{H}: \alpha^{*}=\alpha_{\mathrm{i}}-\alpha_{\mathrm{H} / \mathrm{H}}, \delta_{\mathrm{iH}}$ denotes the probability that at a randomly chosen locus of an individual, one allele come from the ith breed and the other from the $\mathrm{H} / \mathrm{H}$. It was derived as $\delta_{\mathrm{iH}}=\alpha_{\mathrm{i}}^{\mathrm{S}} \mathrm{a}_{\mathrm{H} / \mathrm{H}} \mathrm{D}+$ $\alpha_{\mathrm{H} / \mathrm{H}}{ }^{\mathrm{S}} \alpha_{\mathrm{i}}^{\mathrm{D}}$, where $\alpha_{\mathrm{i}}^{\mathrm{S}}$ and $\alpha_{\mathrm{i}}^{\mathrm{D}}$ were the breed $\mathrm{i}$ contribution of the sire and dam of the individual, and $\alpha_{H / H} \mathrm{~S}$ and $\alpha_{H / H} \mathrm{D}$ were the $\mathrm{H} / \mathrm{H}$ contribution of the sire and dam of the individual, respectively (Wolf et al., 1995).

These analyses were performed using the MIXED procedure of SAS (SAS Institute, 2014) with the ESTIMATE statement.

\section{Average daily gain of different breed groups}

The linear regression coefficient of weight on age $x(\beta)$ represents the average daily gain of the cows of each breed group. For the breed groups analyzed from $4 \mathrm{yr}$ of age to $8.5 \mathrm{yr}$ of age, these coefficients $\beta$ are in the range from $0.15 \mathrm{~kg} / \mathrm{d}(\mathrm{N} / \mathrm{NH}, \mathrm{N} / \mathrm{H}, \mathrm{H} / \mathrm{H}$, and $\mathrm{A} / \mathrm{H})$ to

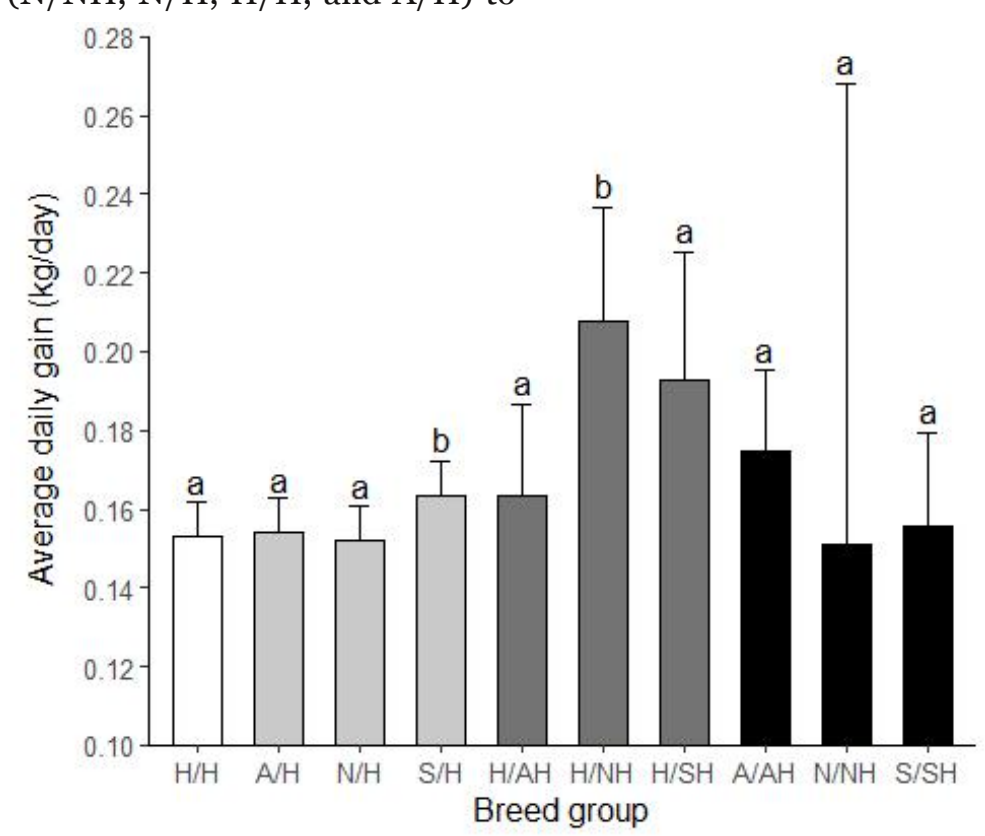

Sire and dam breed group at the left and right of the slash, respectively. Breed group: Hereford (H/H), Angus/Hereford (A/H), Nellore/Hereford (N/H), Salers/Hereford (S/H), Hereford/Angus-Hereford (H/AH), Hereford/Nellore-Hereford (H/NH), Hereford/Salers-Hereford (H/SH), Angus/Angus-Hereford (A/AH), Nellore/Nellore-Hereford (N/NH) and Salers/Salers-Hereford (S/SH)

Figure 1. Average daily gain $(\beta)$ from 4 to $8.5 \mathrm{yr}$ of age per breed group. Error bars represent the s.e. of the means, while different letters indicate significant differences among the breed groups.
$0.21 \mathrm{~kg} / \mathrm{d}(\mathrm{H} / \mathrm{NH})$. The growth rates tended to be more similar according to the $\mathrm{H} / \mathrm{H}$ percentage than according to the breed origin. Only two breed groups had a significantly-different growth rate from $\mathrm{H} / \mathrm{H}$ between 4 and $8.5 \mathrm{yr}$ of age: $\mathrm{S} / \mathrm{H}(0.16 \mathrm{~kg} / \mathrm{d}, \mathrm{P}<0.001)$ and $\mathrm{H} / \mathrm{NH}(0.21 \mathrm{~kg} / \mathrm{d}, \mathrm{P}=0.05)$ (Figure 1$)$. 
Previous reports have shown that Bos indicus $\times$ Bos taurus crossbred steers aged about 10 mo present higher average daily gain than Bos taurus $\times$ Bos taurus crossbred animals (0.18 and $0.07 \mathrm{~kg} / \mathrm{d}$, respectively) feeding ad libitum pasture hay diet (Frisch and Vercoe, 1977). Other study compared average daily gain of $\mathrm{H} / \mathrm{H}, \mathrm{A} / \mathrm{A}$ and their crossbred heifers on two levels of feed (high and low plane of nutrition) and they report gains of 0.82 and $0.73 \mathrm{~kg} / \mathrm{d}$ for crossbred and purebred heifers, respectively, on the high plane, and 0.30 and $0.36 \mathrm{~kg} / \mathrm{d}$ on the low, thus with an interaction between level of nutrition and breed (Wiltbank et al., 1969). The level of nutrition in this study is likely more similar to the low plane given grazing condition of our herd, so our result differs from this study since the average daily gain of crossbred cows involving $\mathrm{A} / \mathrm{A}$, and $\mathrm{H} / \mathrm{H}$ did not differ significantly from $\mathrm{H} / \mathrm{H}$.

\section{Estimated mature weight of different breed groups}

The results of the least-square means by breed group from 4 to 6 yr of age will be presented in Table 3 .

Table 3. Mature cow weight $(\mathrm{kg})$ for breed group by age.

\begin{tabular}{|c|c|c|c|c|c|}
\hline \multirow[b]{2}{*}{ Breed group } & \multicolumn{5}{|c|}{ Age of cows (yr) } \\
\hline & 4 & 4.5 & 5 & $5 \cdot 5$ & 6 \\
\hline \multicolumn{6}{|l|}{ Purebred } \\
\hline $\mathrm{H} / \mathrm{H}$ & $357 \pm 3.4$ & $368 \pm 3 \cdot 7$ & $376 \pm 3 \cdot 5$ & $383 \pm 3 \cdot 7$ & $387 \pm 4.0$ \\
\hline \multicolumn{6}{|l|}{$F 1$} \\
\hline $\mathrm{A} / \mathrm{H}$ & $367 \pm 3 \cdot 4^{*}$ & $378 \pm 3 \cdot 3^{*}$ & $386 \pm 3.5^{*}$ & $393 \pm 3.7^{*}$ & $397 \pm 4.0^{*}$ \\
\hline $\mathrm{N} / \mathrm{H}$ & $398 \pm 3 \cdot 9^{* * *}$ & $409 \pm 3.8^{* * *}$ & $417 \pm 3 \cdot 9^{* * *}$ & $423 \pm 4.0^{* * *}$ & $428 \pm 4 \cdot 3^{* * *}$ \\
\hline $\mathrm{S} / \mathrm{H}$ & $377 \pm 3 \cdot 5^{* * *}$ & $390 \pm 3.5^{* * *}$ & $400 \pm 3.6^{* * *}$ & $409 \pm 3.8^{* * *}$ & $415 \pm 4 \cdot 1^{* * *}$ \\
\hline \multicolumn{6}{|l|}{ Backcrosses } \\
\hline $\mathrm{H} / \mathrm{AH}$ & $335 \pm 13.8$ & $348 \pm 13.0$ & $358 \pm 13.4$ & $367 \pm 14.9$ & $374 \pm 17 \cdot 3$ \\
\hline $\mathrm{H} / \mathrm{NH}$ & $417 \pm 13.2^{* * *}$ & $437 \pm 12.2^{* * *}$ & $456 \pm 13 \cdot 2^{* * *}$ & $472 \pm 16.0^{* * *}$ & $487 \pm 19.7^{* * *}$ \\
\hline $\mathrm{H} / \mathrm{SH}$ & $360 \pm 12.5$ & $378 \pm 11.4$ & $394 \pm 13.2$ & $408 \pm 16.9$ & $420 \pm 21.6$ \\
\hline $\mathrm{A} / \mathrm{AH}$ & $353 \pm 15.2$ & $368 \pm 14.5$ & $380 \pm 14 \cdot 7$ & $391 \pm 15.8$ & $399 \pm 17.6$ \\
\hline $\mathrm{N} / \mathrm{NH}$ & $375 \pm 25.2$ & $385 \pm 16.8$ & $393 \pm 29.0$ & $399 \pm 48.1$ & $404 \pm 68.5$ \\
\hline $\mathrm{S} / \mathrm{SH}$ & $395 \pm 15.5^{*}$ & $406 \pm 14 \cdot 7^{*}$ & $415 \pm 15 \cdot 1^{*}$ & $422 \pm 16.5^{*}$ & $427 \pm 18.8^{*}$ \\
\hline
\end{tabular}

Breeds: $\mathrm{A} / \mathrm{A}=$ Angus, $\mathrm{H} / \mathrm{H}=$ Hereford, $\mathrm{N} / \mathrm{N}=$ Nellore, $\mathrm{S} / \mathrm{S}=$ Salers. Sire and dam breed group at the left and right of the slash, respectively.

Asterisks indicate significant differences between breed group and Hereford: ${ }^{* *}, \mathrm{P}<0.001$ or ${ }^{*} \mathrm{P}<0.05$.

All breed groups increased in their weight from 4 to 6 yr of age. The weight gain between 4 and 6 yr of age of $\mathrm{H} / \mathrm{H}$ and $\mathrm{F} 1$ was about $8 \%$. A similar pattern was observed in the backcrosses to $\mathrm{N} / \mathrm{N}$ and $\mathrm{S} / \mathrm{S}$. On the other hand, the increase in that period in $\mathrm{H} / \mathrm{H}$ backcrosses was between 12 and $17 \%$, which indicates that they reach the MW at ages more advanced. These patterns did not necessarily imply differences in MW.

Estimates of breed-group means for MW were slightly lower than other estimates for the same breeds at similar ages for other authors (Arango et al., 2004). However, unlike the present study, they used improved pastures and supplemental silage or hay during the experimental period.

Weights of $\mathrm{A} / \mathrm{H}$ were significantly heavier than $\mathrm{H} / \mathrm{H}$ $(\mathrm{P}<0.05)$ by a difference of about $10 \mathrm{~kg}$ at every age, which is roughly $3 \%$ of MW1. Arango et al. (2002) reported similar results, in their study reciprocal $\mathrm{H} / \mathrm{A}$ cows were heavier than both $\mathrm{A} / \mathrm{A}$ and $\mathrm{H} / \mathrm{H}(\mathrm{P}<0.01)$ by differences that tended to increase with age from 18 $\mathrm{kg}$ ( $2 \mathrm{yr}$ of age) to $29 \mathrm{~kg}$ (7 $\mathrm{yr}$ of age). The N/H cows were also consistently heavier $(\mathrm{P}<0.001)$ than $\mathrm{H} / \mathrm{H}$ at every age by differences that remained at $41 \mathrm{~kg}$ (11\%). A similar situation was reported by Arango et al. (2004). They reported $\mathrm{N} / \mathrm{H}$ to be heavier than $\mathrm{H} / \mathrm{H}$ from $45 \mathrm{~kg}$ at $2 \mathrm{yr}$ of age to $35 \mathrm{~kg}$ at $6 \mathrm{yr}$ of age. The $\mathrm{H} / \mathrm{NH}$ backcrosses showed the highest superiority from $\mathrm{H} / \mathrm{H}$ ranging from 60 at $4 \mathrm{yr}$ of age to $100 \mathrm{~kg}$ at 6 yr of age $(\mathrm{P}<0.001)$. The $\mathrm{S} / \mathrm{H}$ cows were significantly heavier than $\mathrm{H} / \mathrm{H}$, with differences that tended to increase with age ranging from 20 (6\%) to $28 \mathrm{~kg}(7 \%)$ $(\mathrm{P}<0.001)$. The $\mathrm{S} / \mathrm{SH}$ cows also showed a superiority from $\mathrm{H} / \mathrm{H}$ of roughly $40 \mathrm{~kg}(\mathrm{P}<0.05)$. Arango et al. (2004) also founded that $\mathrm{S} / \mathrm{H}$ outweighed $\mathrm{H} / \mathrm{H}$ by approximately $60 \mathrm{~kg}$ from 2 to $6 \mathrm{yr}$ of age.

The number of records used for estimating means of $\mathrm{H} / \mathrm{H}$ and $\mathrm{F} 1$ was higher than for backcrosses, this is reflected in the standard error of the estimates. While for the F1 groups the standard errors are from $3.3 \mathrm{~kg}$ (A/H at $4.5 \mathrm{yr}$ of age) to $4.0 \mathrm{~kg}(\mathrm{~N} / \mathrm{H}$ at $6 \mathrm{yr}$ of age), for backcrosses they are from $11.4 \mathrm{~kg}(\mathrm{H} / \mathrm{SH}$ at $4.5 \mathrm{yr}$ of age) to $68.5 \mathrm{~kg}(\mathrm{~N} / \mathrm{NH}$ at $6 \mathrm{yr}$ of age). 
Table 4. Estimates of crossbreeding parameters for mature weight $(\mathrm{kg})$ by age.

\begin{tabular}{|c|c|c|c|c|c|}
\hline & \multicolumn{2}{|c|}{ Age of cow (yr) } & \multirow[b]{2}{*}{5} & \multirow[b]{2}{*}{5.5} & \multirow[b]{2}{*}{0} \\
\hline & 4 & 4.5 & & & \\
\hline $\begin{array}{r}/ \mathrm{H} \\
(\mathrm{kg}) \\
\end{array}$ & $361.0 \pm 3.3$ & $368.9 \pm 3.3$ & $377.9 \pm 3.4$ & $384.4 \pm 3.6$ & $389.0 \pm 4.0$ \\
\hline \multicolumn{6}{|c|}{ Additive effects } \\
\hline $\mathrm{g}_{\mathrm{A}}^{\mathrm{I}}$ & $-20.1 \pm 30.8$ & $-9.6 \pm 29.4$ & $-2.4 \pm 29.8$ & $5.1 \pm 32.0$ & $12.7 \pm 35.6$ \\
\hline $\mathrm{g}_{\mathrm{N}}^{\mathrm{I}}$ & $-10.6 \pm 50.7$ & $-9.3 \pm 34.0$ & $-10.0 \pm 58.2$ & $-10.6 \pm 96.3$ & $-10.8 \pm 137.1$ \\
\hline $\mathrm{g}_{\mathrm{S}}^{\mathrm{I}}$ & $47.7 \pm 31.1$ & $53.0 \pm 29.8$ & $51.5 \pm 30.6$ & $50.6 \pm 33.5$ & $49.6 \pm 38.0$ \\
\hline \multicolumn{6}{|c|}{ Heterosis } \\
\hline $\mathrm{h}_{\mathrm{AH}}^{\mathrm{I}}$ & $14.9 \pm 16.1$ & $12.5 \pm 15.4$ & $8.8 \pm 15 \cdot 7$ & $5.5 \pm 16.8$ & $1.9 \pm 18.7$ \\
\hline $\mathrm{h}_{\mathrm{NH}}^{\mathrm{I}}$ & $44.5 \pm 25.9$ & $47.0 \pm 17.8^{\dagger}$ & $46.7 \pm 29.6$ & $46.8 \pm 48.5$ & $46.3 \pm 68.8$ \\
\hline $\mathrm{h}_{\mathrm{SH}}^{\mathrm{I}}$ & $-4.0 \pm 16.4$ & $-5.6 \pm 15 \cdot 7$ & $-3.1 \pm 16.1$ & $-0.5 \pm 17.6$ & $1.8 \pm 19.9$ \\
\hline
\end{tabular}

Hereford least-square means for mature weight \pm standard error of the additive - dominant model. $\mathrm{g}_{\mathrm{A}}^{\mathrm{I}}, \mathrm{g}_{\mathrm{N}}^{\mathrm{I}}$, and $\mathrm{g}_{\mathrm{S}}^{\mathrm{I}}$ are the individual additive effects of Angus, Nellore, and Salers as deviation from Hereford. $\mathrm{h}_{\mathrm{AH}}^{\mathrm{I}}, \mathrm{h}_{\mathrm{NH}}^{\mathrm{I}}$, and $\mathrm{h}_{\mathrm{SH}}^{\mathrm{I}}$ are the individual heterosis between Angus - Hereford, Nellore - Hereford and Salers - Hereford, respectively. The mean followed by ${ }^{\dagger}$ significantly differs from Hereford $(\mathrm{H} / \mathrm{H})$ with $\mathrm{P}<\mathrm{0.1}$.

\section{Additive and non-additive genetic effects}

Crossbreeding effects from 4 to $6 \mathrm{yr}$ of age are presented in Table 4.

The $\mathrm{g}^{\mathrm{I}}$ of A/A did not have significant differences to $\mathrm{H} / \mathrm{H}$ for MW at any age. Morris et al. (1987) comparing these breeds reported from 6 to $14 \mathrm{~kg}$ of superiority from $\mathrm{H} / \mathrm{H}$. Melucci et al. (2006) obtained $\mathrm{g}_{\mathrm{A}}^{\mathrm{I}}$ of $-43.5 \mathrm{~kg}$ when comparing to $\mathrm{H} / \mathrm{H}$. The $\mathrm{g}^{\mathrm{I}}$ of N/N had a non-significant effect for MW at any age, which is in agreement with the result of Boenig (2011) for crosses between $\mathrm{H} / \mathrm{H}$ and Brahman. Non-significant estimates for $\mathrm{g}^{\mathrm{I}}$ of $\mathrm{S} / \mathrm{S}$ were found for MW in the range of ages studied. Theunissen et al. (2013) estimated additive effects of cow weight at calving for Afrikander and cows of different breed origins. The direct effects were $62.6 \mathrm{~kg}$ for Brahman (Zebu breed), $10.2 \mathrm{~kg}$ and $180.1 \mathrm{~kg}$ for Simmental and Charoláis (Continental breeds), and 48.8 for $\mathrm{H} / \mathrm{H}$ as deviation from Afrikander. These results show a significant difference in size among Continental breeds.

The $\mathrm{h}^{\mathrm{I}}$ between $\mathrm{A} / \mathrm{A}$ and $\mathrm{H} / \mathrm{H}$ had a non-significant effect even though the absolute values were as high as those reported by other authors. Cundiff (1970) reported $12.5 \mathrm{~kg}$ of $\mathrm{h}_{\mathrm{A} / \mathrm{H}}^{\mathrm{H}}$ for adjusted weight by the condition score of cows from 6 to $9 \mathrm{yr}$ of age ( $\mathrm{P}<$ 0.05). Melucci et al. (2006) reported the highest value (27.6 kg; P < 0.05) for these breeds. Similar estimates were found by Morris et al. (1987), reporting between $23 \mathrm{~kg}$ and $26 \mathrm{~kg}$. Arango et al. (2004) indicated that the levels of heterosis between $\mathrm{A} / \mathrm{A}$ and $\mathrm{H} / \mathrm{H}$ tended to decrease with age. At $2 \mathrm{yr}$ of age they found $19 \mathrm{~kg}$ of heterosis $(\mathrm{P}<0.01)$, at 3 and $4 \mathrm{yr}$ of age the value was $17 \mathrm{~kg}(\mathrm{P}<0.01)$ and at $6 \mathrm{yr}$ of age the estimate was $5 \mathrm{~kg}$ $(\mathrm{P}<0.05)$.
The $\mathrm{h}^{\mathrm{I}}$ between $\mathrm{N} / \mathrm{N}$ and $\mathrm{H} / \mathrm{H}$ had a significant effect at $4.5 \mathrm{yr}$ of age being of $47.0 \mathrm{~kg}(\mathrm{P}<0.1)$. Other crossbreeding experiments carried out at Texas University reported similar estimates for Brahman $\mathrm{H} / \mathrm{H}$ crosses $47.9 \mathrm{~kg}$ for $\mathrm{F} 1$ and $34.9 \mathrm{~kg}$ for F2 (Boenig, 2011) and $32.7 \mathrm{~kg}$ for $\mathrm{F} 1$ and $42.1 \mathrm{~kg}$ for F2 (Key, 2005).

The estimate of $\mathrm{h}^{\mathrm{I}}$ between $\mathrm{S} / \mathrm{S}$ and $\mathrm{H} / \mathrm{H}$ was nonsignificant. Theunissen et al. (2013) indicate $39.5 \mathrm{~kg}$ of heterosis for cow weight at calving for $\mathrm{H} / \mathrm{H}$ Simmental crosses and, $-27.1 \mathrm{~kg}$ for $\mathrm{H} / \mathrm{H}$ - Charoláis crosses. These results differ from the obtained in our study, but Continental breeds have a wide range of weights, and the authors did not find similar studies involving Salers breed.

The effects of heterosis are known to be higher for traits with low heritabilities, such as reproduction traits (Arthur et al., 1999). Nevertheless, MW has been reported within the groups of traits with medium-high heritabilities, ranged from 0.28 in Hereford using repeated measure mean at $4 \mathrm{yr}$ of age (Meyer, 1995) to 0.56 for Angus at the same age (Costa et al., 2011). Despite the reported heritability values, heterosis levels have been important both in this study for $\mathrm{N} / \mathrm{H}$ at $4.5 \mathrm{yr}$ of age and in those found in the literature.

Regarding the evolution of heterosis with age, we did not find differences. Other studies emphasize that the heterosis effects on size-related traits are largely exhibited by the age of $1 \mathrm{yr}$ and are maintained to maturity (Gregory et al., 1992) or that the levels decrease with age (Smith et al., 1976; Arango et al., 2004). 
The use of an animal model, which considers all genetic relationships, is a more complete method of analysis for crossbreeding data. The relationship matrix was not available for the data set used in this study. However, since sires were balanced across the cow-breed group and at least one was repeated per breed per year, in addition to the fact that the cows of the general herd (without known genealogy) were rotating every year, the use of an animal model is expected to provide little additional information.

The crossbreeding parameters in this study were estimated for different ages since the time when the cows reach the MW is not clear, and different growth patterns have been reported for different breeds. Some authors have reported that the cows would reach their mature weight at $5 \mathrm{yr}$ of age (Kaps et al., 1999; Goldberg and Ravagnolo, 2015), 6 yr of age (Boenig, 2011), or at more advanced ages: $7 \mathrm{yr}$ of age (Gregory et al., 1992; Choy et al., 2002). Contrary, Arango et al. (2004) analyzing the weight of British, Continental, and Zebu cows found that by $4 \mathrm{yr}$ of age, the cows had accumulated most of their final weight (98.6 \%). Other authors have reported that Nellore reaches maturity at about 3 to $5 \mathrm{yr}$ of age (Mercadante, 2001; Rosa et al., 2001).

\section{Conclusions}

In this study, we aimed to estimate MW and crossbreeding parameters for the same trait in crossbred animals of breeds from divergent origins. The use of crosses increased the MW, especially for the F1 animals, with a pattern that increased when the racial groups were genetically more diverse. The crossbred animals with $\mathrm{H} / \mathrm{H}$ sire and $\mathrm{F} 1 \mathrm{H} / \mathrm{N}$ dam showed the highest MW, which supports the previous and current evidence that more heterosis is generated in the Bos taurus $\times$ Bos indicus crosses. According to

\section{Acknowledgements}

We gratefully acknowledge to Caja Notarial de Seguridad Social for the financial support and Facultad de Agronomía (Uruguay) for providing the data for this study. We greatly appreciate the editor and reviewers for the careful work and valuable comments, which helps for improving the manuscript. We also
Regarding the accuracy of the estimates, the additive genetic effect presented high standard errors, roughly twice the standard error of heterosis estimates. It has been reported that the accuracy of the estimate of heterosis is always higher than the accuracy of the additive genetic effects (approximately $20 \%$ fewer animals are required to obtain the same accuracy) (Cunningham and Connolly, 1989). The lack of MW records of purebred cows and reciprocal crosses may have led to high estimates of standard errors. The structure of the data may not be enough for the accurate estimation of parameters in this characteristic. More animals and breed groups would likely have obtained greater precision in the estimates, and more parameters would have had a significant effect.

Further analyzes that allow reducing the standard error or quantifying the probability of differences in the mature weight of the cows at the ages analyzed can provide information to consider in the design of commercial crossbreeding.

\section{Literature Cited}

Arango, J. A., L. V. Cundiff, and L. D. Van Vleck. 2002. Breed comparisons of Angus, Brahman, Hereford, Pinzgauer, Sahiwal, and Tarentaise for weight, weight adjusted for condition score, height, and body condition score. J. Anim. Sci. 80: 3142-3149.

Arango, J. A., L. V. Cundiff, and L. D. Van Vleck. 2004. Comparisons of Angus, Charolais, Galloway, Hereford, Longhorn, Nellore, Piedmontese, Salers, our results, for herds in which crossbred animals are kept to maturity either as dams or for marketing, improved environmental management may be needed to allow the crossbred animals to express its full potential. Further investigation of the causes underlying the differences between breed groups and the application of alternative statistical methods are warranted for a more comprehensive assessment of MW.

thank Gabriel Ciappesoni and Jorge Urioste for the nice suggestions and discussion during the data analyses. The research that generated the results presented in this publication received financial support from the National Agency of Research and Innovation of Uruguay (POS_NAC_2016_1_129902).

and Shorthorn breeds for weight, weight adjusted for condition score, height, and condition score of cows. J. Anim. Sci. 82: 74-84.

Arthur, P. F., H. Hearnshaw, and P. D. Stephenson. 1999. Direct and maternal additive and heterosis effects from crossing Bos indicus and Bos taurus cattle: Cow and calf performance in two environments. Livest Prod Sci 57: 231-241. 
Boenig, L. 2011. Heterosis and heterosis retention for reproductive and maternal traits in Brahman $x$ Hereford crossbred cows. Doctoral thesis, Texas A\&M University, $79 \mathrm{pp}$.

Chenoweth, P. J. 1994. Aspects of reproduction in female Bos indicus cattle: a review. Aust Vet J 71: 422-426.

Choy, Y., J. Brinks, and R. M. Bourdon. 2002. Repeated-measure animal models to estimate genetic components of mature weight, hip height, and body condition score. J. Anim. Sci. 80: 2071-2077.

Costa, R., Misztal, I., Elzo, M. A., Bertrand, J. K., Silva, L. O. C., and Łukaszewicz, M.. 2011. Estimation of genetic parameters for mature weight in Angus cattle. J. Anim. Sci. 89: 2680-2686.

Cundiff, L. V. 1970. Experimental Results on Crossbreeding Cattle for Beef Production. J. Anim. Sci. 30: 694-705.

Cunningham, E. P., and J. Connolly. 1989. Efficient design of crossbreeding experiments. Theor. Appl. Genet. 78: 381-386.

Di Marco, O. 2006. Rendimiento de res. La industria cárnica latinoamericana 26.

Dickerson, G. E. 1969. Experimental approaches to utilizing breed resources. In: Animal Breeding Abstract. p 191-202.

Dickerson, G. E. 1973. Inbreeding and heterosis in animals. Proceedings of the Animal Breeding and Genetics Symposium in Honour of J.L. Lush.: 54-77.

Frisch, J. E., and J. E. Vercoe. 1977. Food intake, eating rate, weight gains, metabolic rate and efficiency of feed utilization in Bos taurus and Bos indicus crossbred cattle. Anim. Prod 25: 343-358.

Gardner, C. O., and S. A. Eberhart. 1966. Analysis and Interpretation of the Variety Cross Diallel and Related Populations. Biometrics 22: 439-439.

Gimeno, D., S. Avendaño, and R. Severino. 1995. Elección de un diseño óptimo de cruzamientos en un experimento con cuatro razas bovinas. In: Memorias de la XIV Reunión Latinoamericana de Producción Animal. p 914-918.

Goldberg, V., and O. Ravagnolo. 2015. Description of the growth curve for Angus pasture-fed cows under extensive systems1. J. Anim. Sci. 93: 4285-4290.

Gregory, K. E., and L. V. Cundiff. 1980. Crossbreeding in Beef Cattle: Evaluation of Systems1. J. Anim. Sci. 51: 1224-1242.

Gregory, K. E., L. V. Cundiff, and R. M. Koch. 1992. Breed effects and heterosis in advanced generations of composite populations on actual weight, adjusted weight, hip height, and condition score of beef cows. J. Anim. Sci. 70: 1742-1754.
Jenkins, T. G. 2009. Interbreed evaluation of beef cattle productivity under low and moderate dry matter availables. In: Procedings of the 18th Association for the Advancement of Animal Breeding and Genetics. $p$ $113-116$.

Junior, C. K., Roso, V. M., Fávaro, P. D., Pereira, G. R., Borges, M. H., Junior, F. A., Barcellos, J. O., and Ribeiro, E. L. . 2019. Heritability estimation and genetic correlations for mature weight, visual scores, and growth traits in Nellore cattle. R. Bras. Zootec. 48:e220170246.

https://doi.org/10.1590/rbz4820170246

Kaps, M., W. O. Herring, and W. R. Lamberson. 1999. Genetic and environmental parameters for mature weight in Angus cattle. J. Anim. Sci. 77: 569-574.

Key, K. L. 2005. Heterosis and heterosis retention for reproductive and maternal traits in Brahman British crossbred cows. Doctoral thesis, Texas A\&M University, $96 \mathrm{pp}$.

Kinghorn, B. P., and P. E. Vercoe. 1989. The effects of using the wrong genetic model to predict the merit of crossbred genotypes. Anim. Prod 49: 209-216.

Koch, R. M. 1972. The Role of Maternal Effects in Animal Breeding: VI. Maternal Effects in Beef Cattle. J. Anim. Sci. 35: 1316-1323.

Kuehn, L., and R. Thallman. 2016. Across-breed EPD tables for the year 2016 adjusted to breed differences for birth year of 2014. Procedings of the Beef Improvement Federation: 127-154.

Lema, O. M., D. Gimeno, N. J. Dionello, and E. A. Navajas. 2011. Pre-weaning performance of Hereford, Angus, Salers and Nellore crossbred calves: Individual and maternal additive and nonadditive effects. Livest Prod Sci 142: 288-297.

Melucci, L. M., C. A. Mezzadra, and E. L. Villarreal. 2006. Genetic components for breeding system traits in Angus-Hereford crossing. Proceedings of the 8th World Congress on Genetics Applied to Livestock Production, Belo Horizonte, Minas Gerais, Brazil, 13-18 August, 2006: 03-51.

Mercadante, M. E. 2001. Análise de um experimento de seleção para crescimento em bovinos Nelore: respostas direta no peso ao sobreano e correlacionadas no tamanho e reprodução das matrizes. Tesis Doctoral, Universidade de São Paulo.

Meyer, K. 1995. Estimates of genetic parameters for mature weight of Australian beef cows and its relationship to early growth and skeletal measures. Livest Prod Sci 44: 125-137.

Morris, C. A., R. L. Baker, A. H. Carter, and J. C. Hunter. 1987. Reciprocal crossbreeding of angus and hereford cattle 3. cow weight, reproduction, 
maternal performance, and lifetime production. New Zealand Journal of Agricultural Research 30: 453-467.

Pravia, M. I., O. Ravagnolo, J. I. Urioste, and D. J. Garrick. 2014. Identification of breeding objectives using a bioeconomic model for a beef cattle production system in Uruguay. Livest Prod Sci 160: 21-28.

R Development Core Team. 2016. A language and environment for statistical computing. $\mathrm{R}$ Foundation for Statistical Computing, Vienna, Austria. ISBN 3-900051-07-0.

Riley, D., and J. Crockett. 2006. Heterosis retention and the dominance model in Florida beef research. Florida Cattleman 70: 42-46.

Rosa, A. D. N., R. B. Lôbo, H. N. D. Oliveira, L. A. F. Bezerra, and A. D. L. Reyes Borjas. 2001. Peso adulto de matrizes em rebanhos de seleção da raça Nelore no Brasil. Revista Brasileira de Zootecnia 30: 1027-1036.

SAS Institute. 2014. 13. 2 User's Guide: HighPerformance Procedures, Cary, NC.

Smith, G. M., H. A. Fitzhugh, L. V. Cundiff, T. C. Cartwright, and K. E. Gregory. 1976. Heterosis for maturing patterns in Hereford, Angus and Shorthorn cattle. J. Anim. Sci. 43: 380-388.
Sobek, Z., A. Nienartowicz-Zdrojewska, J. RóżańskaZawieja, and I. Siatkowski. 2015. The evaluation of gestation length range for different breeds of Polish dairy cattle. Biometrical Letters 52: 37-45.

Sölkner, J., and W. Fucks. 1994. ODCE Optimun Design Design of Crossbreeding Experiments. Version 1.O.

Sölkner, J., and J. W. James. 1990a. Optimum design of crossbreeding experiments: I. A basic sequential procedure. J. Anim. Breed. Genet 107: 61-67.

Sölkner, J., and J. W. James. 199ob. Optimum design of crossbreeding experiments: II. Optimum relationship structures of animals within and between genetic groups. J. Anim. Breed. Genet 107: 411-420.

Theunissen, A., M. M. Scholtz, and F. W. C. Neser. 2013. Crossbreeding to increase beef production: additive and non-additive effects on weight traits. S. Afr. J. Anim. Sci 43: 143-152.

Wiltbank, J. N., C. W. Kasson, and J. E. Ingalls. 1969. Puberty in crossbred and straightbred beef heifers on two levels of feed. J. Anim. Sci. 29: 602-605.

Wolf, J., O. Distl, J. Hyánek, T. Grosshans, and G. Seeland. 1995. Crossbreeding in farm animals. V. Analysis of crossbreeding plans with secondary crossbred generations. J. Anim. Breed. Genet 112: 81-94. 